\title{
PATHOLOGICAL AND BIOCHEMICAL STUDY OF ACUTE FASCOILIOSIS IN CATTLE SLAUGHTERED AT KIRKUK ABATTOIR, KIRKUK, IRAQ
}

\author{
AHMED ABDULLAH SULTAN \\ Department of Pathology and Poultry Diseases, Faculty of Veterinary Medicine, Tikreet University
}

Received: 19 May 2019; Accepted: 22 July 2019

\begin{abstract}
Liver fluke disease (fascioliosis) is an important parasitic disease may accountable for morbidity and mortality in most species of animals, like cattle, sheep and goat as well as other domestic ruminants. It occurs worldwide due to infection with liver fluke species. The study aimed to notice the gross, microscopic lesions and measured serum biochemical changes accompanied with acute bovine liver Fascioliosis of cattle in Kirkuk. From March to April 2018, fifteen infected bovine livers of different ages were collected from Kirkuk abattoir, and examined grossly. A noticeable rise in the level of serum AST, ALP and also ALT were observed. In gross examination several short vermiform cords were observed on the hepatic surface and the surface had a rough appearance. Some immature, wandering flukes were noted on the cut surface. Histopathologically, a wide range of liver lesions were found. The most important lesions were moderate to severe perihepatitis and haemorrhagic tracts on the hepatic surface. These lesions related to migratory channels filled with blood, fibrin and cellular debris. The present study results indicated that serum biochemical alterations were consistent with pathological lesions; hence the analysis of serum biochemical could be used in diagnosis of acute bovine fasciolosis with other tests.
\end{abstract}

Key words: Acute Fascioliosis, cattle, liver flukes, serum biochemical, liver lesions, histopathological examination.

\section{INTRODUCTION}

Liver fluke infection was caused by Fasciola hepatica and F.gigantica and it remains economically important parasite of livestock and is emergent zoonotic infection. In most mammalian species liver fluke causes morbidity and mortality and by far important in cattle (Hodzic et al., 2013). A study accompanied by Keyyu et al. (2006), stated up to $100 \%$ liver attack rates in slaughter slabs in Tanzania in cattle. The prevalence of cattle fasciolosis in Ethiopia was as high as $83.08 \%$ (Mulualem, 1998). The variant in conditions of climato-ecological such as temperature, rainfall and altitude, and management system of livestock influences the incidence of fasciolosis together with distribution and survival of the parasites as well as snails (the intermediate host). Clinical examination of the infected animal with the Fasciola showed anemia or pale visible mucous membrane (Radostits et al., 2017). On post mortem of infected liver with fasciolosis was an irregular outline, firm and pale. Acute fasciolosis is associated with the migrating of immature flukes through the parenchymal liver and make migratory tracts. In this case, grossly the liver becomes haemorrhagic and

Corresponding author: Dr. Ahmed Abdullah Sultan E-mail address: alsultan5877@tu.edu.iq

Present address: Department of Pathology and Poultry Diseases, Faculty of Veterinary Medicine, Tikreet University enlarged with fibrinous to fibrous exudates on the surface of liver capsule. Several haemorrhagic spots and focal necrosis were set up on the cut surface of parenchymal liver. The tracts of migratory from direct trauma of the Fasciola is macroscopically seen as dark acute haemorrhagic lines of typical post necrotic granulation and scarring (Affroze et al., 2013).

Histopathologically the migratory tracts formed by migrating of immature flukes through the hepatic parenchyma were seen as tracts of necrosis (Steyl, 2009). In the liver, the lesions are only partially a result of liver fluke mechanical action, because the liver injury can be induced by Fasciola excretory products, decomposed products of Fasciola, bile and liver tissue. Hence the tests of serum biochemical including enzymes of serum liver are also supportive to evaluate the severity of injury of hepatic cells and to monitor the evolution of the disease in animals (Lee et al., 2005). The analysis of serum biochemical also used to assess the degree of cholestasis and the capacity synthesizing of the liver (Hodzic et al., 2013). So, the study's objectives were to measure pathological variations of the liver, hepatic lymph nodes and gall bladder; to assess serum biochemical variations associated with acute infection with liver fluke, and to start association between pathological changes and serum biochemical parameters of the cattle liver. 


\section{MATERIALS AND METHODS}

\section{Samples Collection}

In this study, fifteen livers of cattle were examined in Kirkuk abattoir. A weekly visit was made to the abattoir at the period of the examination that extended from March to April 2018. The age of animals ranged between months to up 3 year for both sexes.

\section{Blood samples and Separation of serum}

Four hundred blood samples were collected from cattle before slaughtering. Blood sample was collected from the jugular vein in vacutainers without anticoagulant for biochemical analysis including AST, ALP and ALT values were determined by Hitachi 919 (Japan) autoanalayser.

\section{Pathological examination and sampling of tissue}

This study involved collection fifteen (15) samples of bovine livers which were showed sign of infection with flukes were collected from Kirkuki abattoir. This study was carried out from March to April, 2014. During that, fifteen samples from acute bovine liver Fascioliasis at different ages were collected after examination of livers grossly, palpation, incision and noted any changes which detected in the tissue texture of hepatic parenchyma and bile duct. Specimens were fixed with $10 \%$ neutral buffered formalin for 72 hours and then routinely processed. These specimens tissues were embedded in paraffin and sectioned at $5 \mu \mathrm{m}$ thickness and stained sections with the Haematoxylin and Eosin stain then examined microscopically and histological features were recorded. The histopathological sectioning and staining by $H \& E$ stain was performed in tissue process laboratory, Faculty of veterinary medicine, university of Tikrit.

\section{Statistical analysis}

The Statistical Analysis System-SAS (2012) program was used to explain the differences factors in this study parameters. For significant comparison between percentages, Chi-square test has been used to explain results of this study.

\section{RESULTS}

\section{a) Pathological Lesions}

In grossly examination several short vermiform cords were illustrious on the liver surface and the surface had an uneven appearance (Fig. 1). A numerous of immature, wandering flukes were noted on the cut surface (Fig. 2). Migrational tracks were randomly distributed through all areas of the livers, then were most common in the central and left lobes. Color progressively changed from brown-red in the smallest tracks to gray surrounded by a red zone of hyperemia in the larger ones. Tense of the liver capsule with fibrous exudates on the liver capsular surface.

Histopathologically, a wide variety of hepatic lesions were noted. The most important lesions were moderate to severe perihepatitis and haemorrhagic tracts on the liver surface (Fig. 3).These lesions related to migratory channels filled with blood, fibrin and cellular debris (Fig. 4). Migrational tracks were mostly composed with eosinophilic debris of hepatocytic disintegrated and infiltration and aggregation of many eosinophils and neutrophils, macrophages with pigment of haemosiderin and lymphocytes and fewer plasma cell (Fig. 5). Frequently tissue elements surrounding the tracks were affected by a evident coagulative necrosis. (Fig. 6) the neighboring portal areas and the congested sinusoids were plentifully infiltrated by eosinophils, lymphocytes, and macrophages (Fig. 7). Blood vessels thrombosis was frequent in areas adjacent to migrational tracks (Fig. 8). Mural thrombi were less common in arteries than in veins. Central veins thrombosis in migratory areas was moderately general. Arteritis and phlebitis were recurrent in the migratory areas and not necessarily attendant with thrombosis. The biliary tract were less affected than the parenchymal liver in acute form of the Fasciola infection. Multifocal hepatitis \& the necrotic lesions with deep eosinophilic cytoplasm, karyorhexis and karyolysis were observed (Fig. 9 \& 10). There were also mild fibrosis and proliferation of bile duct and distortion of the hepatic cords in some areas (Fig. 11 \& 12). Also, congestion with extensive focal necrosis in parenchyma \& the degenerative changes characterized by vacuolation of the hepatocytes were noted particularly around central vein (Fig. 13).

\section{b) Serum Biochemical Analysis}

Parameters of serum biochemical were compared among animals without visible gross lesion and no Fasciola (group A) and animals with acute fasciolosis (group B), When comparing mean values with that of group A, animals with acute fasciolosis have significantly raised activity of serum ALT, ALP \& AST (Fcalcul.>Ftabul.; P<0.05). 


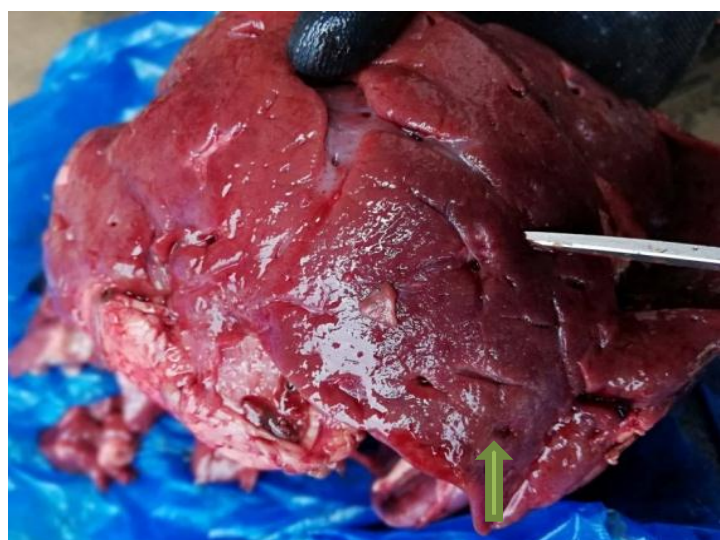

Figure 1: Numerous short vermiform cords on the liver surface with uneven appearance (arrows).

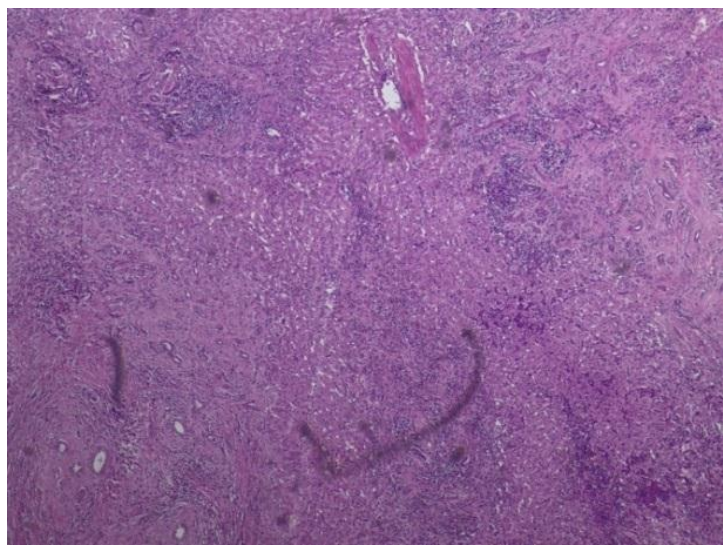

Figure 3: Liver of Cattle showed moderate to severe perihepatitis and haemorrhagic tracts on the liver surface.

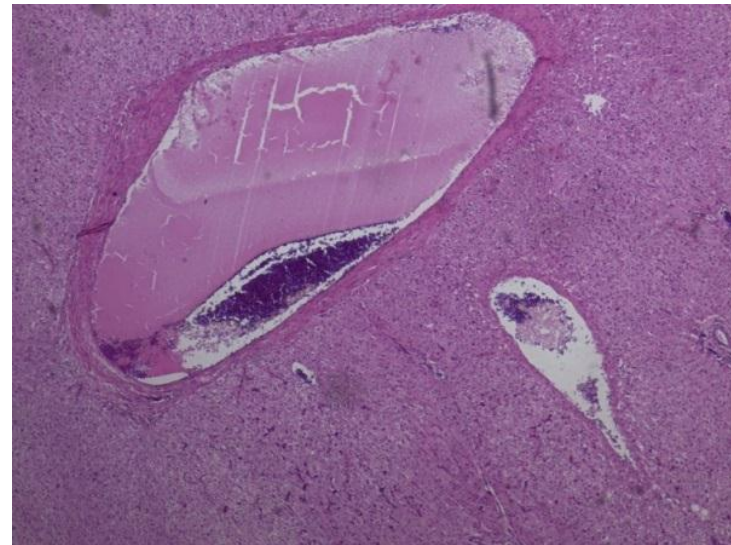

Figure 5: Liver of Cattle showed migrational tracks were mostly composed of eosinophilic debris of hepatocytic disintegrated and infiltration and aggregation of many eosinophils and neutrophils, macrophages with pigment of haemosiderin and lymphocytes and fewer plasma cell

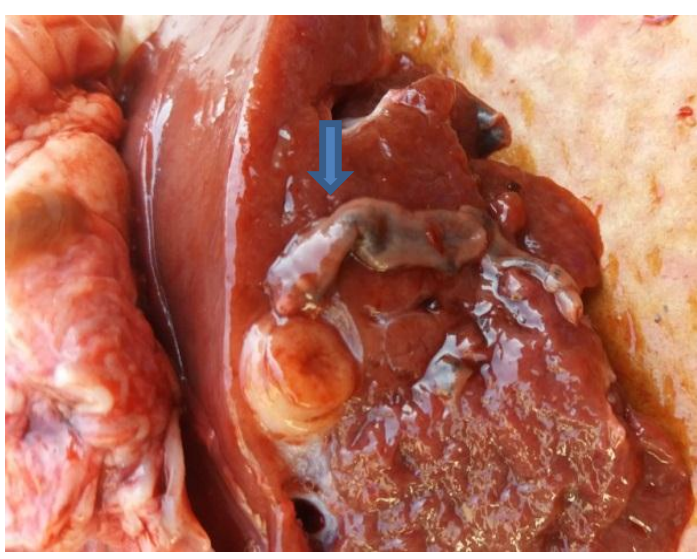

Figure 2: Immature, wandering flukes on the cut surface (arrows).

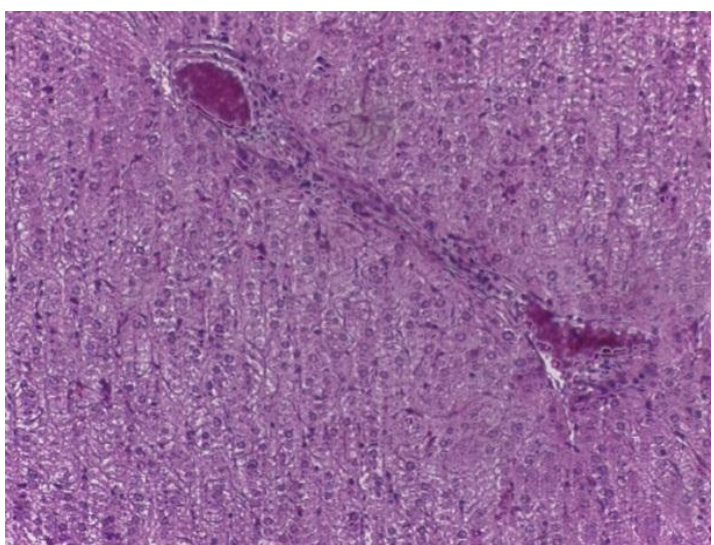

Figure 4: Liver of Cattle showed migratory channels filled with blood, fibrin and cellular debris.

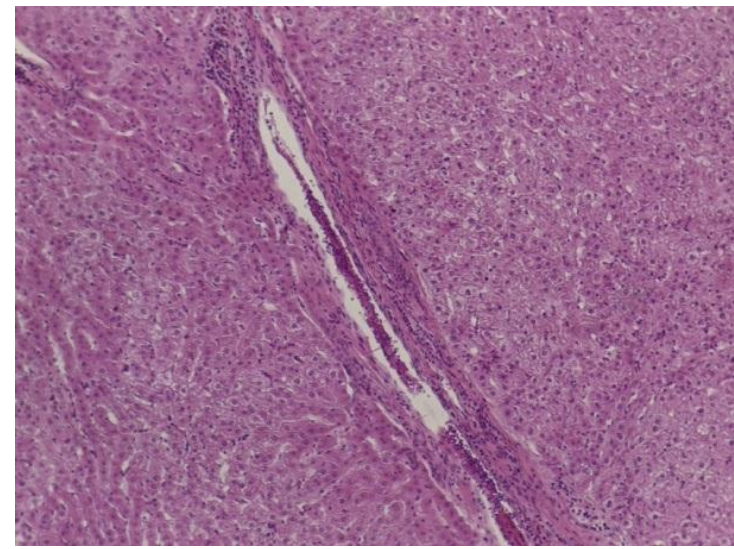

Figure 6: Liver of Cattle showed tissue elements surrounding the tracks were affected by a evident coagulative necrosis 


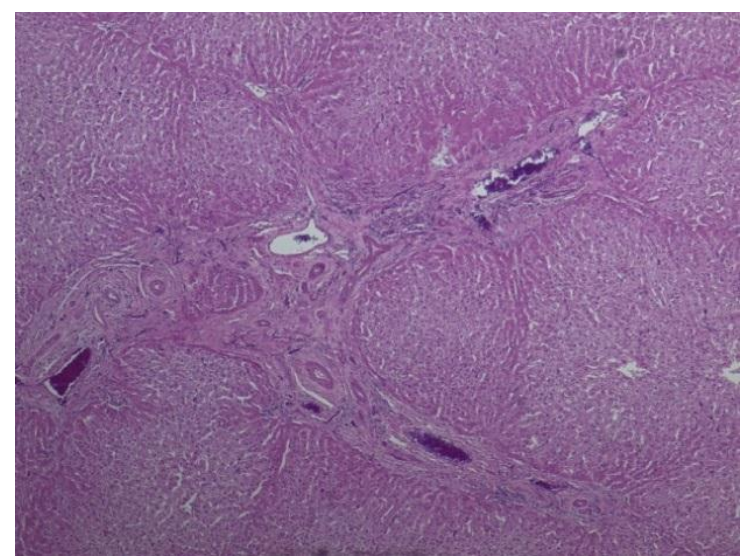

Figure 7: Liver of Cattle showed The neighboring portal areas and the congested sinusoids were plentifully infiltrated by eosinophils, lymphocytes, and macrophages.

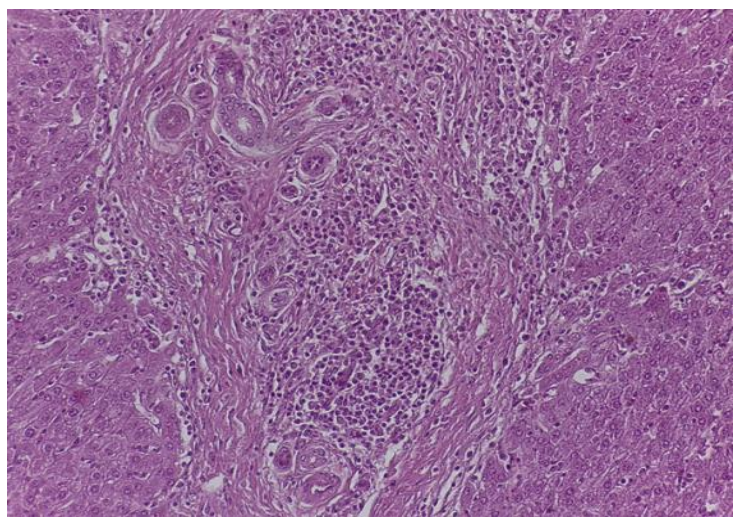

Figure 9: Liver of Cattle showed Multifocal hepatitis \& the necrotic lesions with deep eosinophilic cytoplasm, karyorhexis and karyolysis were observed

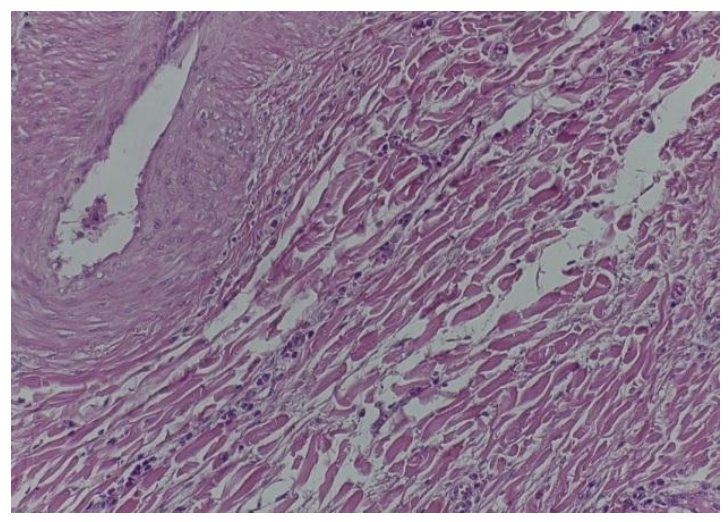

Figure 11. Liver of Cattle showed mild fibrosis and proliferation of bile duct and distortion of the hepatic cords in some areas

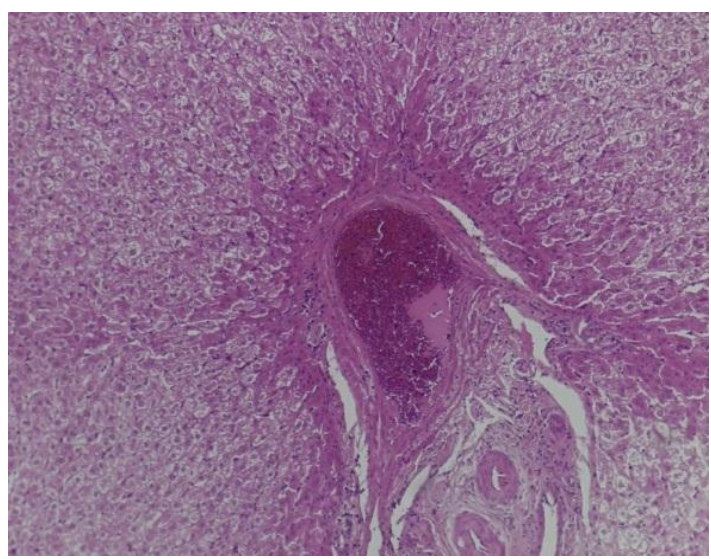

Figure 8: Liver of Cattle showed Blood vessels thrombosis was frequent in areas adjacent to migrational tracks.

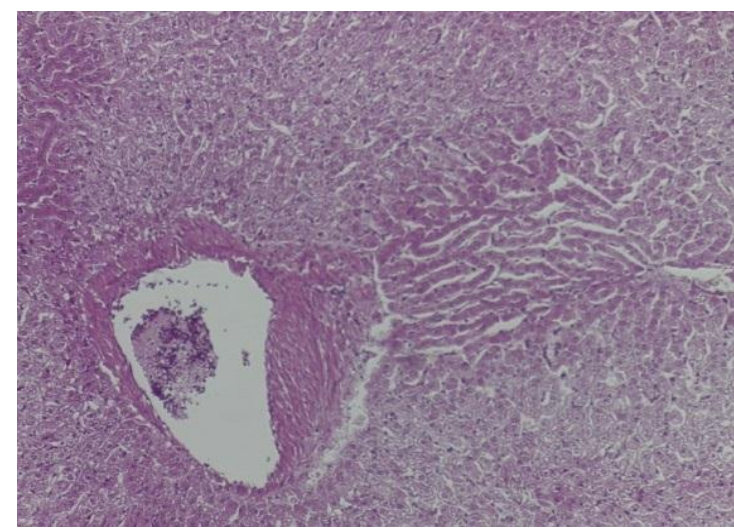

Figure 10: Liver of Cattle showed Multifocal hepatitis \& the necrotic lesions with deep eosinophilic cytoplasm, karyorhexis and karyolysis were observed.

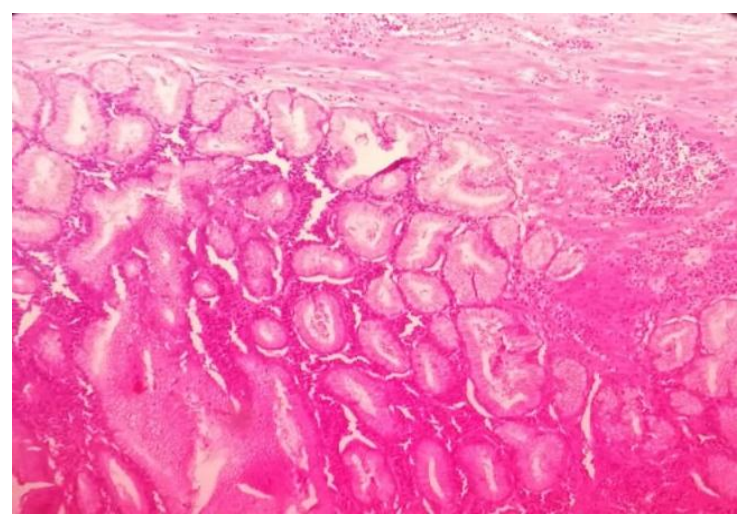

Figure 12. Liver of Cattle showed mild fibrosis and proliferation of bile duct and distortion of the hepatic cords in some areas 


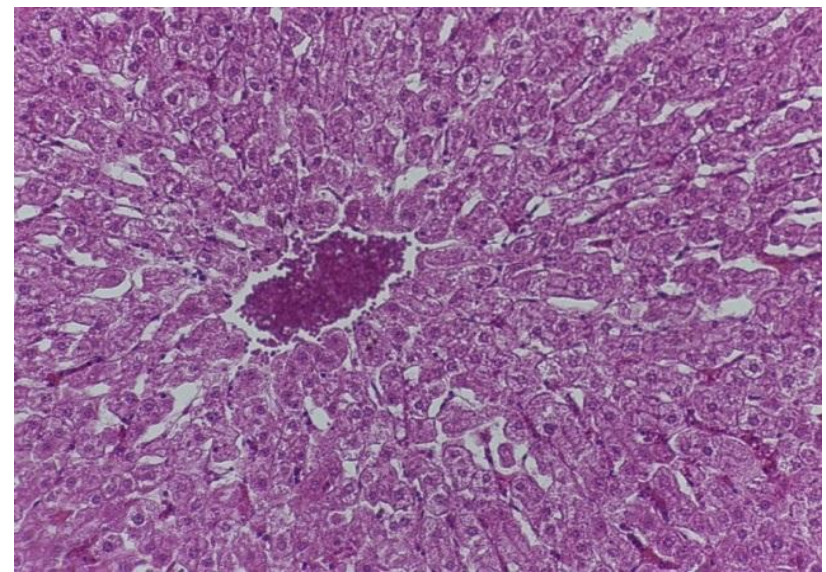

Figure 13: Liver of Cattle showed congestion with extensive focal necrosis in parenchyma $\&$ the degenerative changes characterized by vacuolation of the hepatocytes were noted particularly around central vein

Table 1: Comparisons of some serum liver enzymes among group-A/controls, group-B/ infected Acute Fasciolosis (Mean \pm S.E).

\begin{tabular}{lllll}
\hline Groups & Lesion condition & AST(U/L) & ALT(U/L) & ALP(U/L) \\
\hline Group A & No Visible Lesion & $\mathbf{5 6 . 7 8} \pm 1.08$ & $\mathbf{1 4 . 7} \pm \mathbf{0 . 5 1}$ & $\mathbf{1 4 7 . 9 9} \pm \mathbf{4 . 1 1}$ \\
\hline Group B & Acute Fasciolosis & $\mathbf{7 4 . 0 0 \pm 1 2 . 4 0}$ & $\mathbf{2 1 . 3 0 \pm 7 . 7 4}$ & $\mathbf{2 7 7 . 4 5} \pm 90.55$ \\
\hline
\end{tabular}

\section{DISCUSSIONS}

According to Adrien et al. (2013), there is enlargment of liver in response to acute inflammation as the traveling juvenile fluke mechanically injuries the parenchyma. Molina et al. (2005), also reported at the cut surface, the liver was irregular, firm \& edematous with hemorrhagic channels and adhered fibrosis in the liver parenchyma \& also fibrinous tags on the capsule $\&$ exudates between organs. These authors defensible fibrinous tags on the capsule are due to reaction of capsule to the flukes penetrating it. Supporting the current finding Adrien et al. (2013) and Kitila \& Megersa (2014), stated the hepatic and mesenteric lymph nodes are reactive, enlarged and they oozed edematous material up on opening. Liver abscesses are usually caused by bacterial infections and subsequent lysis of the neutrophils \& are then surrounded by a fibrous capsule. Therefore, multiple soft liver abscesses in our study might be resulted from secondary complication of the bacteria. On the other hand, this may be due to response of the host against fluke infection and continuous mechanical irritation along with parenchymal damage accompanied by severe haemorrhagic lesions \& immunological reactions (El-Hallawany and AbdelAziz, 2012). Also, invasion of the liver by migrating immature liver fluke injuries the tissue and results in decrease of the oxygen tension (anaerobic condition), that allowable the germination \& proliferation spores of Closteridia with associated release of its toxins and prompt hepatocellular necrosis (Jones et al., 1997; Sayed et al., 2008). In our present study, the histopathological investigation also exposed the presence of numerous eosinophils mixed with few lymphocytes \& accompanied by hemorrhage \& edema in acute fascioliosis. These lesions somewhat correlated with the results of Talukder et al. (2010), from liver of goats and completely agreed with state of Borai et al. (2013) and Kitila \& Megersa (2014). Eosinophilia happens due to sensitivity to the parasitic foreign protein, which may be a part of immune phenomena. Therefore, eosinophilia is likely to be seen when flukes are migrating through the tissue in large animals (Kerr, 2002; Borai et al., 2013). Edema \& excessive fluid in interstitial space of hepatocyte may be due to reduction in plasma colloidal osmotic pressure as a result of hypoalbuminemia. In this study the acute cases also shown dilated blood vessels with disorganized \& distortion of the hepatic cords while the hepatocyte revealed variable degrees of necrosis \& degeneration, which are in agreement with Mac Gavin et al. (2017), Sayed et al. (2008), Sohair and Eman (2009) and Kitila \& Megersa (2014). These authors support the consequence as it might be due to mechanical and toxic effects of liver fluke plus immunological reactions affecting the complex vascular \& biliary systems in the liver accompanied by vascular obstruction and distension. In some areas of biliary tract proliferation and mild fibrosis in acute fluke infection of our study might show the previous infection as asymptomatic infection can occur. Adrien et al. (2013), stated extensive damage of liver with the hemorrhagic dark red tracts of necrotic hepatic parenchyma, presence of immature flukes \& thrombosis of the hepatic vessels through the migratory stage are constant features of the liver fluke infection in all species, \& thrombosis happens over areas of localized phlebitis formed by fluke migration. 


\section{a) Serum Biochemical Analysis}

Fasciola causes the release of reactive oxygen types that produce destruction to cell wall $\&$ hepatic tissue necrosis. These changes have an effect on biochemical parameters in serum including liver specific enzymes (Hodzic et al., 2013). There were differences in activities of the liver enzymes like AST, ALT, GGT, ALP, LDH \& GLDH in serum are usually show pathological alterations of tissue \& organ (Tanritanir et al., 2009). In agreement to these reports, the results of the present study revealed a variation in ALT, AST \& ALP values among cattle affected by acute fasciolosis in comparisons with animals with no fasciolosis (Tables:1). When the liver is injured or damaged, the liver enzymes leak into the blood, causing raises of serum liver enzyme (Mert et al., 2006) and Kitila \& Megersa (2014). Different mean values of AST, ALT \& ALP were also measured may arise from physiological adaptations, growth effects, maturation of metabolic pathways, body composition, \& or nutrition (Sharon, 2013). Also, in "Overview of hepatic disease in large animals" these authors stated the levels of serum of liver enzymes differ even with ages, breeds \& sexes. In current study, the mean value of serum liver AST $\&$ ALT were adequately higher $(\mathrm{P}<0.05)$ with acute lesions like degeneration of hepatocyte, telangiectasis $\&$ eosinophilic hepatitis which are in agreement with reports of (Yasuda, 1988), in large animals, serum concentrations of liver enzymes like transaminases are usually higher in acute liver disease than in chronic liver disease. This increase of serum transaminases at the early stage of the infection could be connected to the hepatocellular necrosis \& degenerative changes created by migrating juvenile flukes through the hepatic parenchyma (Dias, 1996). The raise of serum AST \& ALT activity in affection with hepatic parenchyma than in biliary tract destructs in our study also partly agreed with the results of Al-Quraishy and Al-Moussawi (2001). AST is current in both the cytoplasm \& mitochondria of hepatocytes and will raise together with ALT in states of changed membrane permeability (Yasuda 1988), however the mitochondrial AST isoenzyme is fewer likely released with most of the conditions which result in raised membrane permeability (Kerr and Steiner, 2012). ALT is current in high concentration in the cytoplasm of hepatocyte $\&$ is considered to be liver exact in small animals \& ruminants like camel. Its plasma concentration rises with hepatocellular degeneration or damage/necrosis and hepatocyte proliferation (Hodzic et al., 2013). The previous findings of Mbuh and Mbwaye (2005), similarly detected the increase of ALT in fasciolosis may be due to destruction of hepatocyte since ALT is mainly found in the hepatic parenchyma. On the other hand, the elevation in mean value of ALT in this study may be due to death of hepatocyte from liver fluke infection causing complete or partial obstruction of bile ducts and then recurring of bilirubin to hepatocyte (Dias, 1996; Kilad et al., 2000).
According to Adama et al. (2011) and Kitila \& Megersa (2014), serum ALT remain elevated for several days after acute liver fluke infection indicating epithelial injury in the bile ducts which agrees with raised serum ALT in hyperplastic cholangitis in our study. So, in hyperplastic cholangitis AST \& ALT raise may be due to damage of parenchyma as a secondary effect of cholestasis (Salem and Hassan, 2011) and Kitila \& Megersa (2014). Attributing to the report of Kocatepe (2012) and Kitila \& Megersa (2014), elevated serum ALP was though, also recorded with necrosis of hepatocytes in this study; so, hepatic ALP can rise following necrosis of hepatocytes due to secondary intrahepatic biliary obstructions and as part of the nodular regeneration process.

\section{CONCLUSION AND RECOMMENDATIONS}

This study attempted to assess the lesions of liver and serum biochemical variation that accompany liver fluke infection in cattle. Grossly livers were: pale, irregular in outline, firm and tough in consistency. On the other hand, multifocal eosinophilic hepatitis, talengechtasis and different necrosis of hepatocyte and degeneration were histopathologic changes detected in acute cases.

Concentration of analysis of the serum liver enzyme was moreover used to evaluate liver fluke infection and showed significant raise of serum AST and ALT with acute lesions of parenchyma. Based on our study the following recommendations were forwarded: In these study results of serum biochemical deviations were also constant with pathological findings and so, the analysis of serum biochemical could be used as complementary in diagnosis of cattle hepatic fluke infection. In the study we used cattle with no hepatic fluke and no gross hepatic lesions at all, as control groups for comparisons serum biochemical but added experimental studies with case-control should be done to establish better association between liver pathological alterations and serum biochemical variation.

\section{REFERENCES}

Adama, JY.; Ajanusi, OJ.; Chiezey, N. and Lawal, A. (2011): Biochemical responses of yankasa sheep to experimental fasciola gigantica infection in Zaria, Nigeria. Int. J. anim. veter. adv., 3(6): 409-415.

Adrien, ML.; Schild, AL.; Marcolongo-Pereira, C.; Fiss, L.; Ruas, JL.; Grecco, FB. and Raffi, $M B$. (2013): Fasciolose aguda em bovinos no sul do Brasil. Pesq. vet. bras., 33(6): 23.

Affroze, S.; Begum, N.; Islam, MS.; Rony, SA.; Islam, MA. and Mondal, MH. (2013): Risk factors and gross pathology of bovine liver fluke infection at Netrokona district, Bangladesh. J. Anim. Sci. adv., 3(2): 83-90. 
Al-Quraishy, LO. and Al-Moussawi, AM. (2001): Effect of Fasciola gigantica infection on some blood physiological and biochemical aspects of infected cows in Babylon governorate. MSc. thesis; College mof Medicine, University of Babylon. PP. 1-7.

Borai, GM.; Nagi, AA.; Gab-Allah, SM.; El-Mashad, IA. and Moustafa, AS. (2013): Comparative pathological studies on parasitic affections of liver in farm animals. MSc. thesis; Pathology department, Faculty of Veterinary Medicine, Benha University. Pp. 4-8.

Dias, LM.; Silvar, GR. and Viana, HL. (1996): Biliary fascioliasis diagnosis, treatment and follow up by ERcp. Gastr. intest. endos., 43: 16-20.

El-Hallawany, HA. and Abdel-Aziz, MZ. (2012): Clinicohistopathological studies on the correlation between some parasitic infection on liver and ovarian efficiency in small ruminants. J. Repro. infert., 3(3): 67-76.

Hodzic, A.; Zuko, A.; Avdic, R.; Alic, A.; Omeragic, J. and Jazic, A. (2013): Influence of fasciola Hepatica on serum biochemical parameters and vascular and biliary system of sheep liver. Ira. J. Parasitol., 8(1): 92-98.

Jones, TC.; Hunt, RD. and Kind, NW. (1997): Veterinary pathology; $6^{\text {th }}$ ed., Lea Febiger, Philadelphia, USA.146-68.

Kerr, MG. (2002): Veterinary laboratory medicine. Clinical biochemistry and heamatology. $2^{\text {nd }} \mathrm{ed}$. Black well science, Ltd. PP. 86-98.

Kerr, MG. and Steiner, JM. (2012): Diagnostic procedures for the private practice laboratory: A subsidiary of Merck and Co., Inc., White house station, NJ., U.S.A. privacy terms. pp. 36.

Keyyu, JD.; Kassuku, AA.; Msalilwa, LP.; Monrad, J. and Kyvsgaard, NC. (2006): Cross sectional prevalence of helminth infection in cattle on traditional, small scale and large scale dairy farms in Iringa district, Tanzania. Vet. res. commun., 30: 45-50.

Kilad, ZM.; Chpashvili, L.; Abuladze, D. and Jath, VD. (2000): Obstruction of common bile duct caused by liver fluke, F.hepatica. Sblek., 101(3): 255-9.

Kitila, D.B. and Megersa, Y.C. (2014): Pathological and Serum Biochemical Study of Liver Fluke Infection in Ruminants Slaughtered at ELFORA Export Abattoir, Bishoftu, Ethiopia. Global Journal OF Medical Research (C) Volume XIV Issue VIII Version I: 7-20.

Lee, DH.; Lim, JS.; Yang, JH.; Ha, MH. and Jakobs, JR. (2005): Serum gamma glutamyltransferase within its normal range predicts a chromic elevation of alanine aminotransferase: A four year follow-up study. F.rad. res., 39: 589-593.

Mac Gavin, MD.; Carlton, WW. and Zachary, JF. (2001): Thomson's special veterinary pathology. 2nd ed., Mosby, Year book in C.11830, Westline industrial drive. 56-97

Mbuh, JV. and Mbwaye, J. (2005): Serological changes in goats experimentally infected with F. gigantica in Buea sub-division of S.W.P. Camer. J.vet. parasitol., 131(3-4): 255-259.

Mert, H.; Kozat, S.; Ekin, S. and Yörük, I. (2006): Serum sialic acid, lipid-bound sialic acid levels in sheep naturally chronic infected with F.hepatica. Sag. bilim. der., 9: 40-46.

Molina, EC.; Skerratt, LF. and Campbell, R. (2005): Pathology of fasciolosis in large ruminants. Overcoming liver fluke in South east Asia. PP. 94-126.

Mulualem, E. (1998): Epidemiology of bovine fasciolosis in weredas of South Gonder administrative zone bordering Lake Tana. J.E.V.A., 2: 1-14.

Radostits, OM.; Gay, CC.; Blood, DC. and Hinchliff, $K W$. (2017): A text book of the diseases of cattle, sheep, pigs, goats and horses. 10th ed. London: WB Saunders. Pp. 251-98.

Salem, SI. and Hassan, AM. (2011): Clinicopathological, cytological and histopathological studies on liver and kidney affections in camels. Glob. Vet., 7(6): 557-71. 39. Sayed SM, Gehan MS, Neveen AE (2008). Clinicodiagnostic studies on hepatic affections of aged buffaloes. Assi.vet.med. J., 54(117): 310-328.

Sayed, SM.; Gehan, MS. and Neveen, AE. (2008): Clinicodiagnostic studies on hepatic affections of aged buffaloes. Assi.vet.med. J., 54(117): 310-328

Sharon, A. (2013): Enzyme activity in hepatic disease in small animals. In: Merck Sharp and Dohme Corp., a subsidiary of Merck and Co., inc., Whitehouse Station, N.J., U.S.A. pp. 145.

Sohair, IB. and Eman, MN. (2009): Histopathological and bacteriological studies on livers affected with fascioliasis in cattle. Egy.J.comp.path. and clinic. path., 22(1): 1945.

Steyl, JC. (2009): Fasciolosis in livestock. Senior seminar, Department of Pathology, Faculty of Veterinary Science, Onderstepoort. pp.12-23.

Talukder, SI.; Bhuiyan, MJ.; Hossain, MM.; Uddin, MM.; Paul, S. and Howlader, MR. (2010): Pathological investigation of liver fluke infection of slaughtered Bengal goats in a selected area of Bangladesh. Bangl. J.vet.med. 8(1): 35-40.

Tanritanir, P.; Ozdal, N.; Ragbetli, C.; Yoruk, I.; Ceylan, E. and Deger, S. (2009): Some biochemical parameters and vitamins levels in the hair goats naturally mixinfected with ectoparasites (Lice (Linognathus africanus) and Trichostrongylidae spp.). J. Vet. Adv., 8(3): 590-594.

Yasuda, J. (1988): Overview: Fascioliasis and liver damage. Jap. J. Vet. Sci., 50: 71. 


\section{دراسة مرضية وبيوكيميائية عن مرض ديدان الكبد الحاد في الماثية المذبوحة في مسلخ كركوك ، كركوك ، العراق

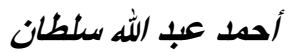 \\ قسم أمر اض الامر اض وامر اض الدواجن ، كلية الطب البيطري ، جامعة تكريت \\ E-mail: alsultan5877@tu.edu.iq Assiut University web-site: www.aun.edu.eg}

مرض ديدان الكبد (اللفافة) هو مرض طفيلي مهم قد يكون مسؤو لاً عن الاصابة و النفوق في معظم أنواع الحيو انات ، مثل الأبو الأبقار

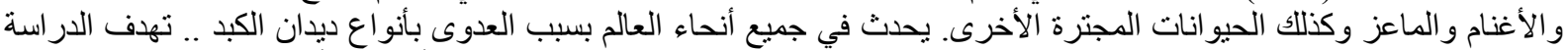

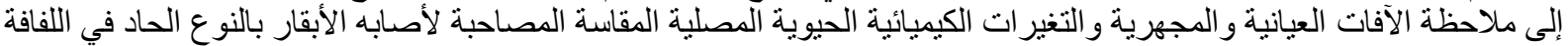

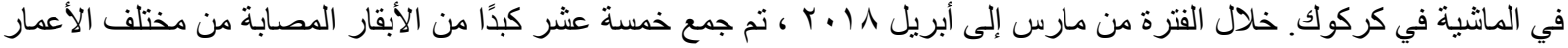

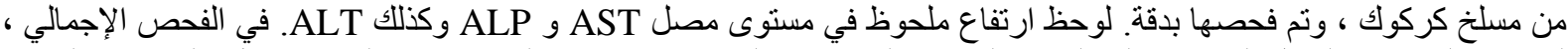

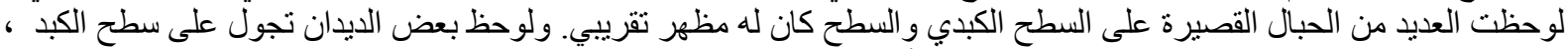

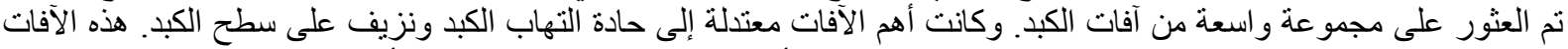

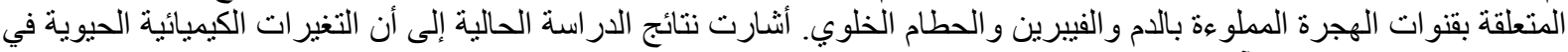

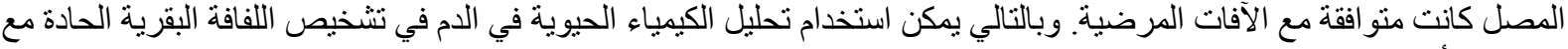
اختبار ات أخرى 